\title{
Sistem Informasi Persediaan Stok Barang Pada Toko Kelontong Berbasis Web
}

\author{
Ni Ketut Sriwinarti, Ikang Murapi*, Nur Fathona \\ Universitas Bumigora \\ sriwinarti@universitasbumigora.ac.id, \\ ikangmurapi11@universitasbumigora.ac.id, nurfathona@gmail.com
}

\begin{abstract}
Abstark
Masalah pada persediaan barang adalah permasalahan operasional yang sering dihadapi oleh sebuah perusahaan. Jika jumlah inventory sedikit dan permintaan tidak dapat dipenuhi karena kekurangan persediaan maka dapat menghambat proses kerja begitu juga apabila inventory terlalu besar, hal ini dapat mengakibatkan kerugian pada perusahaan. Oleh karena itu perusahaan harus bisa memutuskan berapa banyak suatu barang harus di siapkan untuk keperluan penjualan. Selain itu pengolahan data persediaan yang masih manual menyebabkan sering terjadinya selisih saldo barang.

Untuk menghindari kesalahan yang ada, diperlukan sebuah sistem yang disebut sistem informasi pendataan barang yang berbasis website. Tujuan memanfaatkan website agar lebih mudah diakses kapanpun dan dimanapun. Metode pengembangan sistem yang digunakan yaitu metode waterfall. Adapun tahapan tersebut yaitu analisa kebutuhan, perancangan, implementasi, dan testing.

Dari penelitian ini terciptalah sebuah sistem informasi stok barang berbasis website yang dapat bekerja dengan baik, sehingga dapat membantu pengguna mendata barang yang masuk maupun keluar atau jika buat point-point, maka hasil yang diperoleh berdasarkan hasil uji coba adalah sebagai berikut: (1) Aplikasi Sistem Informasi Persediaan Stok Barang telah berhasil dibuat dan dapat diterapkan sebagai sistem informasi dalam mengelola stok barang; (2) Dengan adanya sistem informasi persedian stok barang berbasis web ini, dapat memudahkan staff maupun admin mengelola stok barang; (3) Memberikan informasi stok barang dengan akurat dan actual; (4) Aplikasi ini telah berhasil diuji dan semua fitur-fitur di dalamnya sudah berjalan sebagai mestinya sehingga mempermudah untuk mengelola stok barang
\end{abstract}

Kata Kunci: Persediaan Barang, Sistem Informasi, Toko Kelontong, waterfall 


\begin{abstract}
Problems with inventory are operational problems that are often faced by a company. If the amount of inventory is small and demand cannot be met due to a shortage of inventory, it can hamper the work process as well as if the inventory is too large, this can result in losses to the company. There for the company must be able to decide how much of an item should be prepared for sales purposes. In addition, the manual processing of inventory data causes frequent differences in the balance of goods.

To avoid existing errors, we need a system called a website-based goods data collection information system. The goal is to use the website to make it easier to access anytime and anywhere. The system development method used is the waterfall method. The stages are needs analysis, design, implementation, and testing.

From this research, a website-based inventory information system was created that can work well, so that it can help users record incoming and outgoing goods or if they make points, the results obtained based on the test results are as follows: (1) Application The Inventory Inventory Information System has been successfully created and can be applied as an information system in managing the stock of goods; (2) With this web-based inventory inventory information system, it can make it easier for staff and admins to manage stock items; (3) Provide accurate and actual stock information; (4) This application has been successfully tested and all the features in it are running as they should, making it easier to manage stock items
\end{abstract}

Keyword: Inventory, Information Systems, Grocery Store, waterfall

\title{
Pendahuluan
}

Kios atau toko kelontong adalah usaha kecil yang banyak diminati dan dimiliki oleh masyarakat, usaha ini biasanya tersebar di area perumahan padat perkotaan hingga pedesaan. Yang mana pada prinsipnya kebanyakan dari toko kelontong masih bersifat konvensional. Tidak seperti supermarket atau minimarket, pada toko kelontong para pembeli tidak bisa mengambil sendiri barang-barang yang dibutuhkan, ada rak pembatas antara penjual dan pembeli. Unit usaha toko kelontong dipilih karena lebih dekat dengan kebutuhan masyarakat. Perputaran uang pun relatif cepat sehingga bisa mendukung perekonomian di tingkat wilayah (Wininatin Khamimah, Tegowati, Nenny Syahrenny, 2021).

Sistem keuangan pada usaha ini sebenarnya sangat sederhana tidak dibutuhkan menu yang komplek. Hal terpenting yang dibutuhkan adalah adanya manajemen data berkaitan keluar masuknya barang, karena berdasarkan beberapa pengamatan di kios-kios yang ada pasar khususnya pasar Gerung ditemukan bahwasanya barang-barang sering menumpuk, Ketika sales datang dilakukan pesanan lagi tanpa tahu bahwa barang dikios masih ada atau malah sebaliknya. Proses pengolahan data yang dilakukan pada kios atau toko kelontong kebanyakkan masih menggunakan cara manual, dimana dalam kegiatan operasional sistem persediaan barang masih dicatat menggunakan media kertas, sehingga data barang yang masuk kadang tidak benar atau tidak sesuai dengan 
data yang masuk dari supplier, barang yang dikeluarkan tidak sesuai pesanan, dan dapat terjadi kehilangan data barang yang sudah dicatat.

Masalah pada persediaan barang adalah permasalahan operasional yang sering dihadapi oleh sebuah perusahaan. Jika jumlah inventory sedikit dan permintaan tidak dapat dipenuhi karena kekurangan persediaan (Margareta Nawang, Laela Kurniawati, 2011), maka dapat menghambat proses kerja (Faisal et al., 2013), begitu juga apabila inventory terlalu besar, hal ini dapat mengakibatkan kerugian pada perusahaan. Oleh karena itu perusahaan harus bisa memutuskan berapa banyak suatu barang harus di siapkan untuk keperluan penjualan. Selain itu pengolahan data persediaan yang masih manual menyebabkan sering terjadinya selisih saldo barang (Mukhlisin et al., 2016) karena kesalahan pencatatan dalam proses mutasi barang dikartu stok dan terhambatnya pelaporan persediaan barang dagang, karena data dari kartu stok dipindahkan ke dalam format excel setiap bulannya yang membutuhkan ketelitian dan banyak waktu.

Pandemi COVID-19 yang dialami Indonesia sejak 16 Maret 2020 berpengaruh pada usaha toko kelontong. Usaha ini mengalami penurunan omzet penjualan karena berbagai faktor. Pendapatan masyarakat yang menurun dan jumlah mini market yang masuk perkampungan makin banyak menjadi beberapa faktor penyebabnya. Omzet penjualan adalah akumulasi kegiatan penjualan produk barang dan jasa yang dihitung secara keseluruhan selama kurun waktu tertentu secara terus menerus atau dalam satu proses akuntansi. Omzet penjualan dari tahun ke tahun tidak selalu sama (Putri, 2016). Terdapat 2 (dua) faktor yang mempengaruhi besar kecil omzet usaha yaitu pertama adalah faktor internal atau faktor yang dikendalikan oleh pihak-pihak perusahaan, diantaranya: kemampuan perusahaan untuk mengelola produk yang akan dipasarkan, kebijaksanaan harga, dan promosi yang digariskan perusahaan, serta kebijaksanaan untuk memilih perantara yang digunakan. Sedangkan kedua faktor eksternal atau faktor yang tidak dapat dikendalikan oleh pihak perusahaan, diantaranya: perkembangan ekonomi dan perdagangan baik nasional maupun internasional, kebijakan pemerintah di bidang ekonomi, perdagangan dan moneter, dan suasana persaingan pasar (Rizal et al., 2017).

Berangkat dari permasalahan-permasalahan tersebut, penulis mencoba menawarkan untuk melakukan perubahan sistem pada toko-toko kelontong khususnya yang ada dipasar, dengan dengan menggunakan sistem inventori berbasis website. Salah satu toko kelontong yang dijadikan tempat uji coba adalah Toko Ona. Toko Ona merupakan salah satu toko kelontong, toko kelontong sendiri merupakan toko penyedia barang kebutuhan sehari-hari merupakan usaha mikro yang kepemilikannya dimiliki oleh pribadi dan melakukan penjualan barang, melayani pelanggan secara langsung dan pada umumnya pemilik toko merangkap tugas sebagai kasir. Toko Ona yang berlokasi di Jl. Pendidikan No. 39 Kelurahan Lewirato Kota Bima ini, menjual berbagai macam Alat Tulis Kantor (ATK). Alat Tulis Kantor berarti barang yang dipakai untuk mengerjakan pekerjaan tulis-menulis, mencakup baik kertas, buku-buku, tinta, pensil, karet penghapus, jepitan kertas, kartu- kartu, dan sebagainya. Tidak hanya ATK Toko Ona juga menjual bermacam sembako, dan juga pulsa, akan tetapi Toko Ona lebih 
berfokus pada penjualan ATK, karna letak Toko Ona ini dikelilingi bangunan seperti kantor dan sekolah. Dengan memanfaatkan website, Toko Ona dapat mendata barang dengan mudah dan mengurangi terjadinya kesalahan. Sistem ini juga dapat menyimpan data barang dengan aman.

\section{Metoda Penelitian}

Pengembangan perangkat lunak merupakan suatu strategi pengembanan yang memadukan proses, metode, dan perangkat (tools). Metode - metode pengembangan perangkat lunak, memberikan teknik untuk membangun perangkat lunak yang berkaitan dengan serangkaian tugas yang luas yang menyangkut analisis kebutuhan, kontruksi program, desain, pengujian, dan pemeliharaan. Berdasarkan hal tersebut, maka metode yang digunakan dalam menyelesaikan penelitian ini adalah metode waterfall (Sasmito, 2017), dimana model waterfall merupakan model klasik yang bersifat sistematis, berurutan dalam membangun software. Metode waterfall melewati fase-fase sebagai berikut:

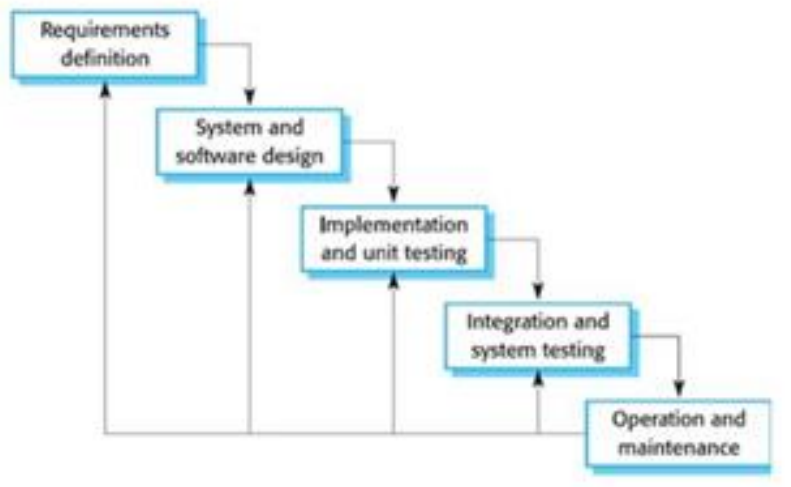

\section{Gambar 1. Metode Waterfall}

\subsection{Analisa kebutuhan}

Analisis pada tingkat teknik pertama, disebut sebagai model analisis yang menggambarkan serangkaian model representasi dari sistem yang akan dibuat yaitu pertama analisis akan kebutuhan sistem berupa kebutuhan akan perangkat lunak, kebutuhan system dan kemampuan sumber daya manusia

\subsection{Desain Sistem}



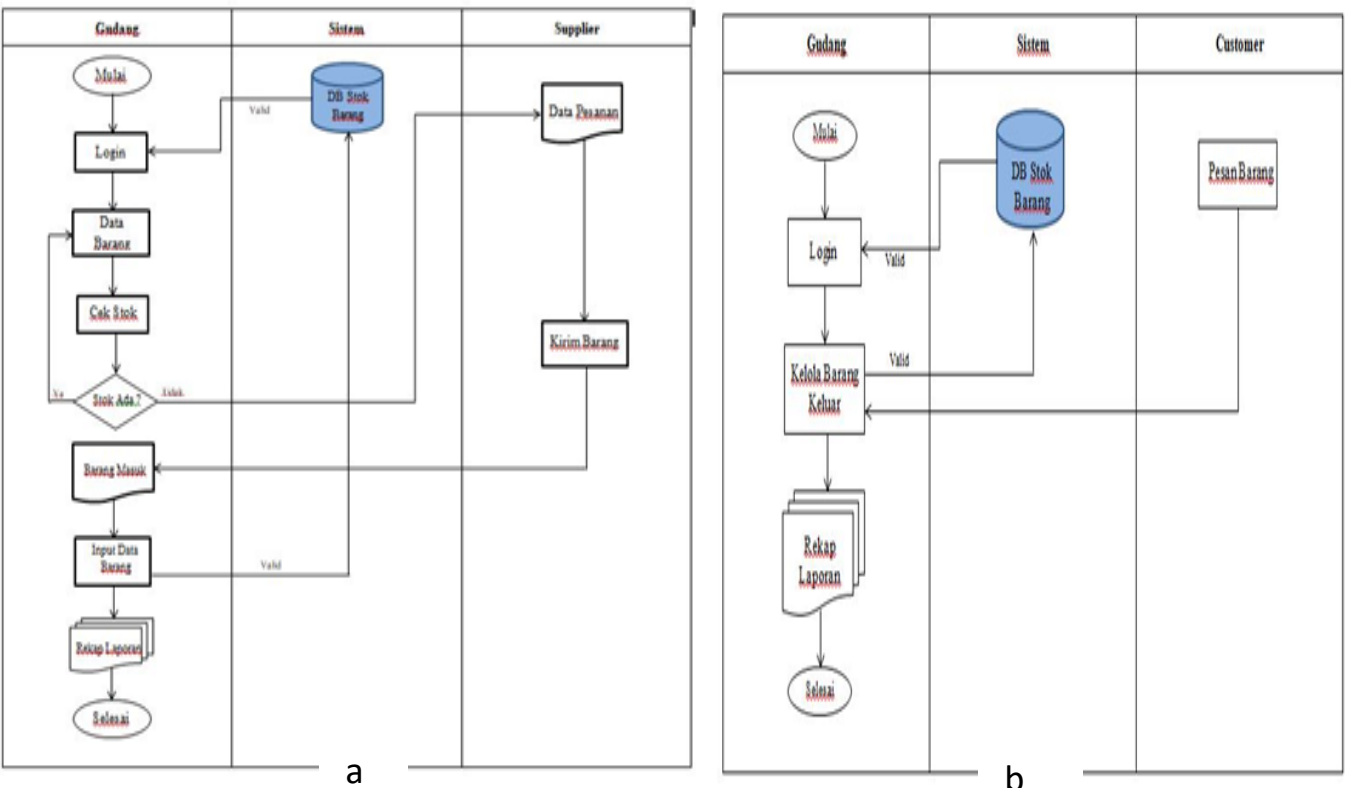

Gambar 2. Desain Alur Sistem Persediaan

Gambar pertama (a) menunjukkan proses barang masuk dimana proses ini diawali dengan bagian gudang melakukan login, setelahnya gudang melihat data barang, jika data barang ada maka tidak melakukan pemesanan, jika barang tidak ada maka gudang melakukan pemesanan pada supplier. Kemudian dari supplier mengirim barang, dan bagian gudang akan menginput data barang yang masuk, setelah penginputan maka data barang akan di rekap. Sedangkan gambar yang kedua (b) menunjukkan sebuah proses yang diawali dengan bagian gudang melakukan login, setelahnya mengelola barang keluar dari pesanan customer, setelah melakukan pengelolaan barang keluar, bagian gudang akan melakukan pengrekapan data barang keluar.

\section{Hasil Dan Pembahasan}

\subsection{Hasil Implementasi}

1). Menu-menu yang tersedia

Pada Aplikasi ini tersedia beberapa menu yang dapat diinputkan oleh pemilik usaha kelontong seperti data barang, kategori barang, barang masuk dan barang keluar. Dimana sebelum masuk ke halaman ini admin harus melakukan login terlebih dahulu dengan menginputkan user dan password demi keamanan data. 


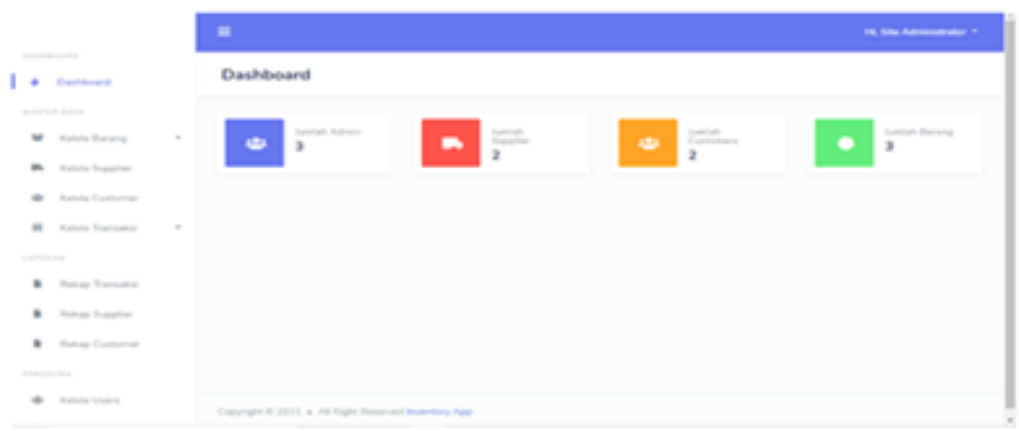

Gambar 3. Tampilan halaman dashboard

2). Menu Data Barang

Halaman ini dimana admin dapat melakukan penginputan barang, edit data barang, dan menghapus data barang.

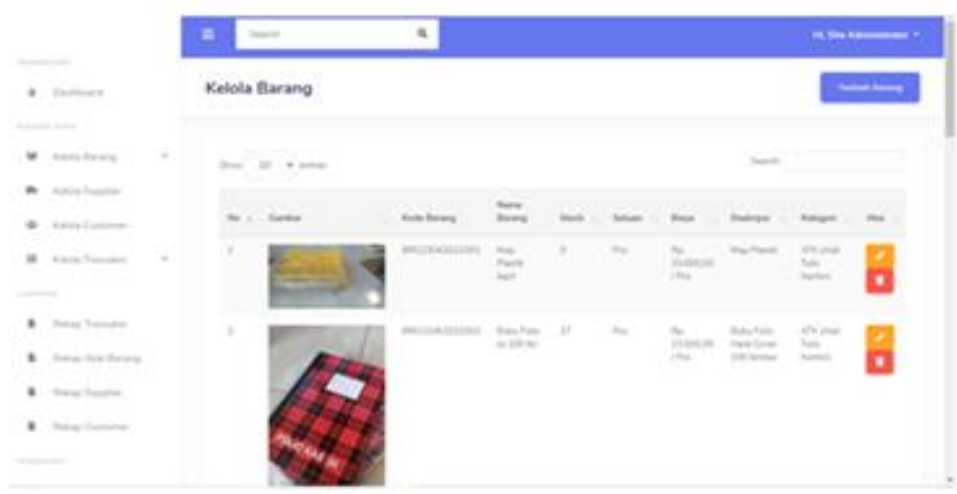

Gambar 4. Tampilan halaman barang

\section{3). Menu Kategori Barang}

Menu ini disediakan untuk mempermudah pemilik usaha dalam mencari kategori barang berdasarkan jenis barang, namun menu ini sebenarnya bisa di hilangkan jika tidak ingin digunakan.

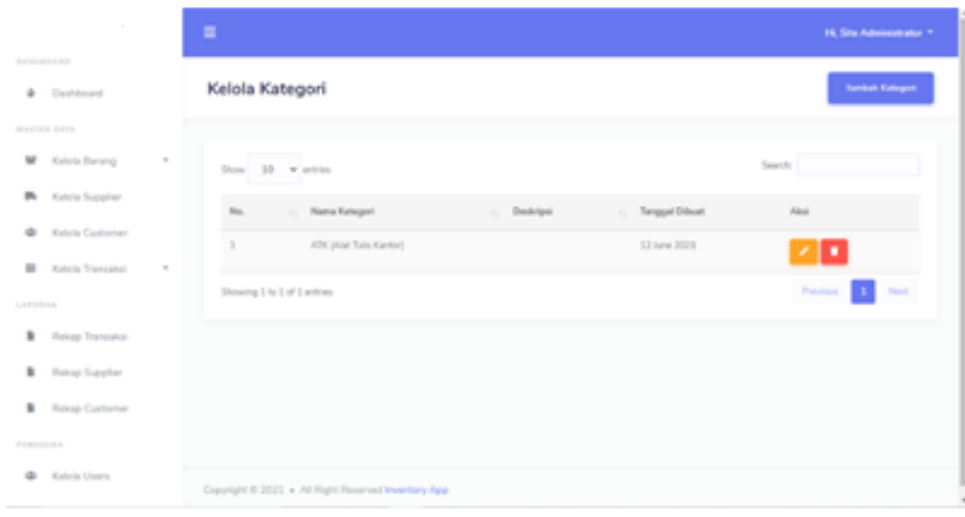

Gambar 5. Tampilan halaman Kelola kategori 
4). Menu Data Supplier

Supplier adalah pihak ketiga yang sangat penting bagi pelaku usaha kecil (kelontong) untuk dapat melihat barang-barang tersebut harus dipesan kemana. Halaman ini dimana admin dapat melakukan data supplier, edit data suppllier, dan menghapus data supplier

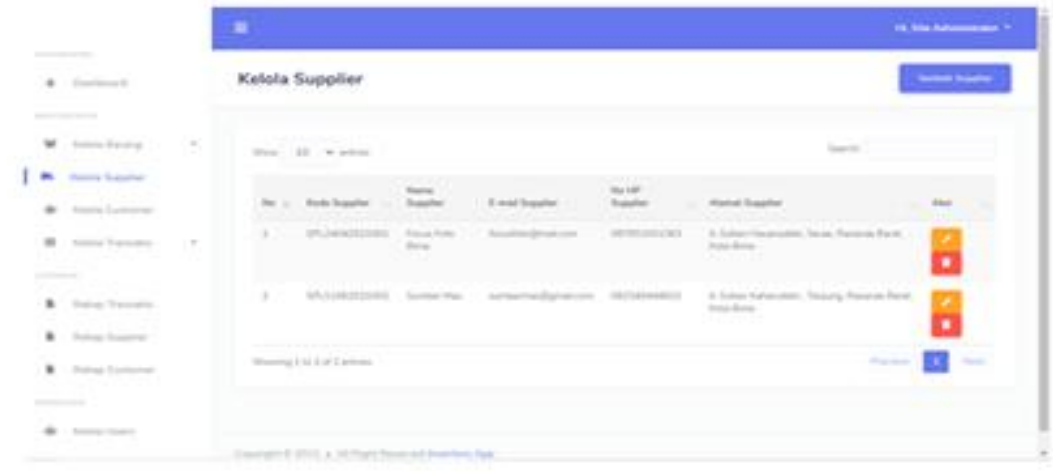

Gambar 6. Kelola Supplier

5). Menu Data Barang Masuk

Halaman ini dimana admin dapat melakukan penginputan barang masuk dan menghapus data barang masuk, pada pendataan barang masuk penulis menggunakan metode average dimana dalam sistem penambahan data barang masuk, jadi harga barang yang masuk akan berubah dari harga sebelumnya, dimana harga barang yang masuk dikalikan dengan stok barang yang masuk, kemudian dibagi dengan stok dan harga barang sebelumnya.

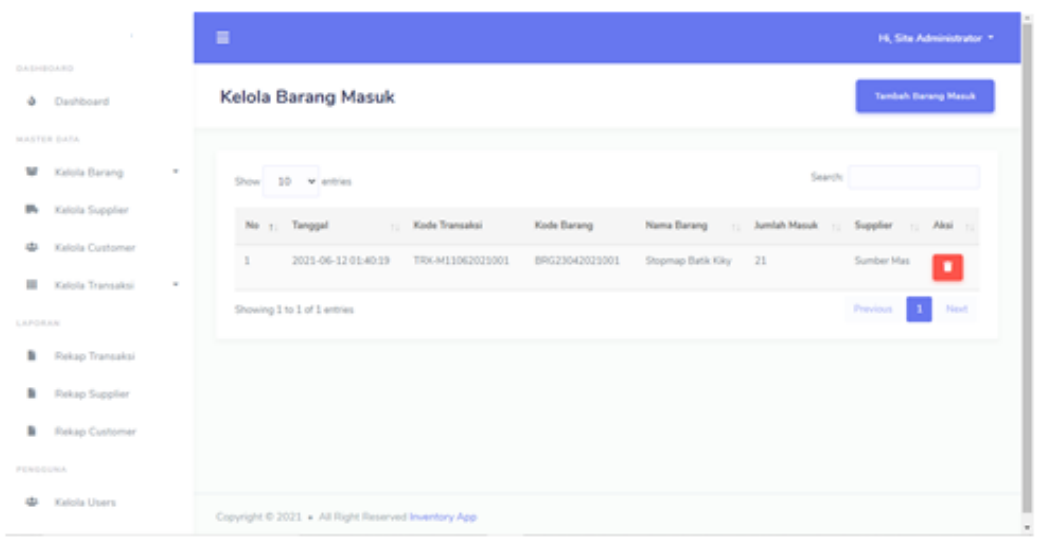

Gambar 7. Tampilan menu Barang Masuk

6). Menu Data Barang Keluar

Halaman ini dimana admin dapat melakukan penginputan barang keluar dan menghapus data barang keluar. 


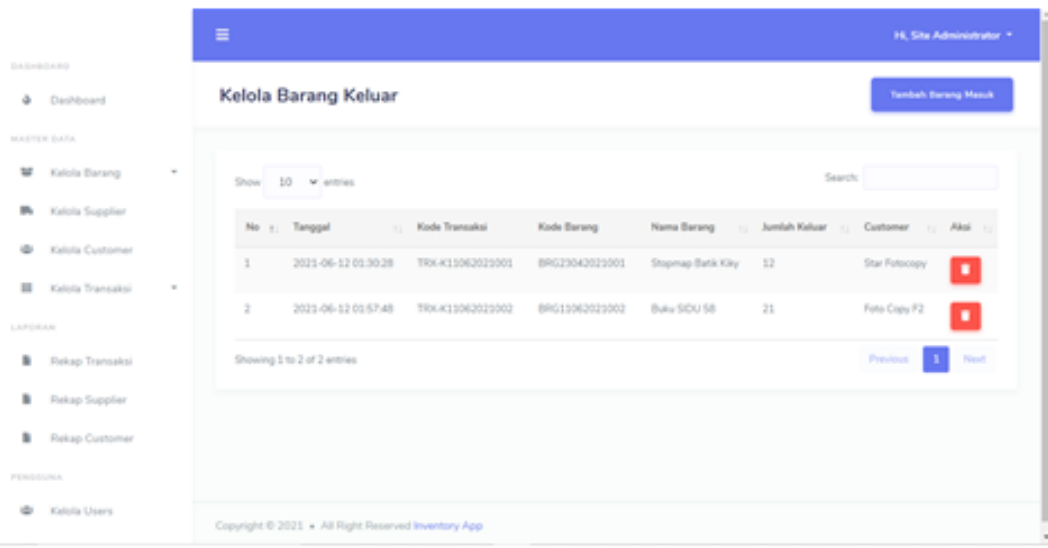

Gambar 8. Tampilan Barang Keluar

\section{7). Menu Stock Barang}

Stock barang adalah menu yang dapat digunakan oleh pemilik usaha untuk melihat barang yang masih ada atau yang tidak ada sehingga dapat membantu untuk melakukan manajemen data barang.

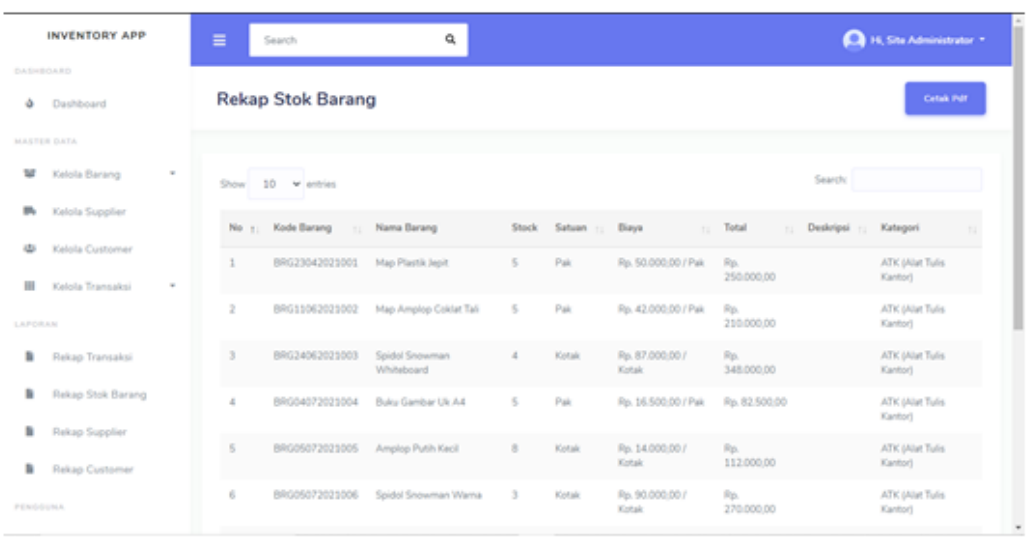

Gambar 9. Tampilan Stock Barang

\subsection{Pengujian fungsi Aplikasi}

Pada tahap pengujian ini menggunakan Teknik pengujian Black-Box. Dimana pada tahap ini akan dilakukan pengujian fungsional dari fitur-fitur yang telah diimplementasi, sehingga dapat dilakukan evaluasi sistem sebelum sistem di gunakan. Berikut adalah Sebagian menu yang telah dilakukan pengujian.

Tabel 1. Pengujian Sistem

\begin{tabular}{|l|l|l|c|}
\hline Skenario Pengujian & \multicolumn{1}{|c|}{ Hasil Yang Diharapkan } & Hasil \\
\hline $\begin{array}{l}\text { Mengosongkan username } \\
\text { dan password kemudian } \\
\text { klik tombol login }\end{array}$ & $\begin{array}{l}\text { Sistem akan menolak dan akan } \\
\text { menampilkan pesan merah "The E- } \\
\text { mail field is required."dan "The } \\
\text { Password field is required." }\end{array}$ & $\begin{array}{c}\text { [J] Diterima } \\
\text { [ ] Ditolak }\end{array}$ \\
\hline
\end{tabular}




\begin{tabular}{|c|c|c|}
\hline Skenario Pengujian & Hasil Yang Diharapkan & Hasil \\
\hline $\begin{array}{ll}\text { Mengosongkan salah satu } \\
\text { field, username } & \text { atau } \\
\text { password kemudian } & \text { klik } \\
\text { tombol login. } & \end{array}$ & $\begin{array}{l}\text { Sistem akan menolak, dan akan } \\
\text { menampilkan pesan merah "The } \\
\text { Password field is required." }\end{array}$ & $\begin{array}{l}{[\sqrt{ }] \text { Diterima }} \\
{[\text { ] Ditolak }}\end{array}$ \\
\hline $\begin{array}{l}\text { Menginput username atau } \\
\text { password salah }\end{array}$ & $\begin{array}{l}\text { Sistem akan menolak dan } \\
\text { menampilkan keterangan "The E-mail } \\
\text { field is required."dan "The Password } \\
\text { field is required." }\end{array}$ & $\begin{array}{l}{[\sqrt{ }] \text { Diterima }} \\
{[\text { ] Ditolak }}\end{array}$ \\
\hline $\begin{array}{l}\text { Menginput username dan } \\
\text { password dengan benar }\end{array}$ & $\begin{array}{l}\text { Sistem akan menerima, dan lansung } \\
\text { masuk ke dashboard }\end{array}$ & $\begin{array}{l}{[\sqrt{]} \text { Diterima }} \\
\text { [ ] Ditolak }\end{array}$ \\
\hline $\begin{array}{l}\text { Mengosongkan } \\
\text { form, kemudian } \\
\text { Simpan Data }\end{array}$ & $\begin{array}{l}\text { Sistem akan menolak dan } \\
\text { menampilkan keterangan "The } \\
\text { Kategori field is required, The Satuan } \\
\text { field is required, The Nama Barang } \\
\text { field is required, The Stok Barang } \\
\text { field is required, The Harga Barang } \\
\text { field is required" }\end{array}$ & $\begin{array}{l}{[\sqrt{ }] \text { Diterima }} \\
{[\text { ] Ditolak }}\end{array}$ \\
\hline $\begin{array}{l}\text { Mengisi beberapa form, } \\
\text { dan mengosongkan } \\
\text { sebagian form, kemudian } \\
\text { klik Simpan Data }\end{array}$ & $\begin{array}{l}\text { Sistem akan menolak dan } \\
\text { menampilkan keterangan "The Stok } \\
\text { Barang field is required, The Harga } \\
\text { Barang field is required" }\end{array}$ & $\begin{array}{l}{[\sqrt{ }] \text { Diterima }} \\
{[\text { ] Ditolak }}\end{array}$ \\
\hline $\begin{array}{lcr}\text { Mengisi } & \text { gambar } & \text { tetapi } \\
\text { tidak } & \text { mengisi } & \text { form, } \\
\text { kemudian } & \text { klik } & \text { Simpan } \\
\text { Data } & & \end{array}$ & $\begin{array}{l}\text { Sistem akan menolak dan } \\
\text { menampilkan keterangan "The } \\
\text { Kategori field is required, The Satuan } \\
\text { field is required, The Nama Barang } \\
\text { field is required, The Stok Barang } \\
\text { field is required, The Harga Barang } \\
\text { field is required" }\end{array}$ & $\begin{array}{l}{[\sqrt{ }] \text { Diterima }} \\
{[\text { ] Ditolak }}\end{array}$ \\
\hline $\begin{array}{l}\text { Mengisi semua form data } \\
\text { barang, kemudian klik } \\
\text { Simpan Data }\end{array}$ & $\begin{array}{l}\text { Sistem akan menerima dan data } \\
\text { barang berhasil ditambah }\end{array}$ & $\begin{array}{c}{[\sqrt{ }] \text { Diterima }} \\
{[\text { ] Ditolak }}\end{array}$ \\
\hline
\end{tabular}

Kesimpulan

Berdasarkan hasil analisis yang telah dilakukan pada point-point sebelumnya maka kesimpulan yang dapat diambil berdasarkan hasil uji coba adalah sebagai berikut: (1) Aplikasi Sistem Informasi Persediaan Stok Barang telah berhasil dibuat dan dapat diterapkan sebagai sistem informasi dalam mengelola stok barang; (2) Dengan adanya sistem informasi persedian stok barang berbasis web ini, dapat memudahkan staff maupun admin mengelola stok barang; (3) Memberikan informasi stok barang dengan akurat dan actual; (4) Aplikasi ini telah berhasil diuji dan semua fitur-fitur di dalamnya sudah berjalan sebagai mestinya sehingga mempermudah untuk mengelola stok barang. Secara aplikasi, system ini telah dibuat, untuk tahap selanjutnya adalah mencoba mengimplementasikan pada kios-kios atau took kelontong yang ada di area pasar. 


\section{Daftar Pustaka}

Faisal, R., Batara, E., Siregar, M., \& Anna, N. (2013). INVENTARISASI GULMA PADA TEGAKAN TANAMAN MUDA Eucalyptus spp. (Weed Inventory on stand of young Eucalyptus spp.). Peronema Forestry Science Journal, 2(2), 44-49-49.

Margareta Nawang, Laela Kurniawati, D. D. (2011). RANCANG BANGUN SISTEM INFORMASI PENGOLAHAN DATA PERSEDIAAN BARANG BERBASIS DEKSTOP DENGAN MODEL WATERFALL. Journal of Cardiothoracic Surgery, 6(1), 233-238. https://doi.org/10.1186/1749-80906-9

Mukhlisin, S. W., Rachmat, H., \& Mulyana, T. (2016). Perancangan Sistem Storage and Retrieval Machine Pada Simulasi Automated Storage and Retrieval System Dengan Memanfaatkan Robotino®. Jurnal Rekayasa Sistem \& Industri (JRSI), 3(01), 27. https://doi.org/10.25124/jrsi.v3i01.38

Putri, C. S. (2016). Rancang Bangun Aplikasi Berbasis Web Persediaan Barang Di Toko “Agen Snack.” Jurnal Manajemen Informatika, 6(1).

Rizal, R., Romidon, H., \& Handika, I. (2017). Analisis Bauran Pemasaran terhadap Omzet Penjualan pada PT. Gaudi Dwi Laras Cabang Palembang. Jurnal Adminika, 3(2), 78-94.

Sasmito, G. W. (2017). Penerapan Metode Waterfall Pada Desain Sistem Informasi Geografis Industri Kabupaten Tegal. Jurnal Informatika:Jurnal Pengembangan IT (JPIT), 2(1), 6-12.

Wininatin Khamimah, Tegowati, Nenny Syahrenny, I. W. (2021). Training and Mentoring Tips To Increase Sales Turnover and Recording Financial Transactions At the Rungkut Grocery Store Cooperative in Surabaya. ABDIMAS GALUH, 3, 143-154. 